\title{
Open Defecation Free (ODF) Program As an Urgent Public Service in Semarang City, Central Java
}

\author{
Hartuti Purnaweni ${ }^{1,2, *}$ \\ ${ }^{1}$ Doctoral Program of Environmental Science, School of Postgraduate Studies, Diponegoro University, Semarang - \\ Indonesia \\ ${ }^{2}$ Department of Public Administration, Faculty of Social Science and Political Science, Diponegoro University, Semarang \\ - Indonesia
}

\begin{abstract}
Semarang is the capital city of Central Java, located in the heart of Java island. However, the number of households practising Open Defecation (OD) is still quite high. This fact is astonishing since Semarang is an urban metropolitan area. Therefore, the municipal government of Semarang set a target of abolishing OD in 2018. This article is focused on awareness of the local dwellers in Jomblang Village, Candisari District, on their OD behavior. Data for this study were collected by library research, observation, and in-depth interviews. The result shows that Open Defecation Free (ODF) is part of Community Based Total Sanitation Program, a segment of important public health service must be provided by the government, but not yet well committed. The local people of Jomblang are not fully aware of the importance of ODF. Successful ODF programme needs active participation of the local dwellers in addition to the responsibility of the government as the public service provider, especially in health service, which is one of the most important service it must provide besides education service. and right page margins and justified.
\end{abstract}

Keywords: Open Defecation Free (ODF); sanitation, public service; health

\section{Introduction}

Sanitation has been amongst the important aspects of human daily life. The United Nations have also responded to such importance by establishing sanitation as part of human rights by 2010. One among the Sustainable Development Goals is universal access to adequate and equitable sanitation and eradication of open defecation by 2030 [1]

However, sanitation still becomes a major problem in developing countries as has been proved in Kenya [2] and also in Indonesia. Sadly, in 2013, Indonesia as ranked the second worst countries in terms of sanitation quality [3]. Therefore the Indonesian government has been launching various programs to increase its sanitation level, such as through creating 100\% sanitation access in 2019, launched in 2013 [4].

The mission of $100 \%$ sanitation access by 2019 is the focus of the Ministry of Health Affairs. In fact, none of province in Indonesia has reached $100 \%$ sanitation in 2014. Jakarta was the highest with $87.2 \%$, while the lowest provinces were East Nusatenggara with 29.7\%, $29.3 \%$ in Bengkulu, and 29.2\% in Papua [5]. The government has been making nationwide efforts in sanitation development as a manifestation of its responsibility for providing public service. In the realm of public administration, the government has the responsibility to provide services to citizens, in particular in the mandatory fields, i.e. health and education.

The Government of Indonesia as the service provider of its citizens has made efforts in health service and health care by establishing sanitation through a Community-based Total Sanitation (STBM) in 2008, with the issuance of Minister of Health Number 852/MENKES/SK/IX/2008 on Community Based Total Sanitation (CBTS) program [6]. This policy was preceded with a cooperation between the Indonesian government and the World Bank in Total Sanitation and Sanitation Marketing (TSSM) Project. This strategy was arranged in an effort of socializing a clean and healthy life, enhancing community's capacity in implementing the government's commitment to increase sustainable clean water and basic sanitation access in achieving Millennium Development Goals (MDGs) in 2015 set by 
the United Nations. This program is then continued with Sustainable Development Goals (SDGs) program, following the end of MDGs.

Through the years sanitation service programs in Indonesia have been dominated by a top-down paradigm in the form of subsidy provision. Meanwhile, the Community-based Total Sanitation program requires a participatory sanitation services towards changes in the citizens' behaviors in the sanitation development [7]. Therefore the sanitation program will sustain more compared to the former type

As Sholikhah [8] writes that sanitation service is provided in two different approaches, i.e. (a) institutionbased approach by putting government offices and work units, local enterprises, and private sectors into action; and (b) community-based approach by involving citizens as the main actors and the ultimate deciders during the service provision, thereby empowerment and active participation.

One among the main problems ahead of sanitation in Indonesia is Open Defecation (OD) practice, part of the global condition of an estimated 892 million people still practice OD [1]. The Open Defecation Free (ODF) must be one of government promises to provide good sanitation and to control the open defecation habit. It is the government's responsibility to provide health service to its people, as one among the most important public service beside education.

The ODF is expected to materialize an attitude and behavioral change, in which the citizens are required to practice the healthy defecation. According to UNICEF/WHO definition, OD is the worst kind of sanitation that materialize in disposing human waste in garbage bins, water bodies, public areas, forests, farmlands or other open and green spaces [9]. Furthermore, the programmer also has a target of providing all citizens with in-house toilets or lavatories. The open defecation behavior in Indonesia occurs either in rural or urban areas in all provinces in Indonesia including in Central Java in general, and Semarang in particular [10]. According to data, 2 (two) out of 10 Central Java citizens do open defecation, as what has been evidenced in Semarang Municipality area, the capital of Central Java Province [11].

To bring the citizens into awareness of hygiene is a difficult task. Efforts must be taken to empower the citizens by giving them knowledge about the importance of clean and healthy life as the starting point towards the change in behavior, including their behavior in materializing free from open defecation life style. In fact, there were 63 millions of Indonesian population without toilets or lavatories, practicing Open Defecation in river, sea, or on the soil surface [12].

According to result of Basic Health Research in 2012, a number of 39-40 million people practicing open defecation, including those having lavatories at home but still practicing open defecation at rivers. Indonesia is blessed with many rivers and therefore river is very much center of life for many Indonesians. Meanwhile, according data from Joint Monitoring
Program UNICEF/WHO in 2014, an amount of 55 million Indonesians still practicing open defecation [4]. According to the World Bank, inadequate sanitation service in Indonesia inhibits the country's economic growth, causing loss as much as 2.3 per cent of the annual GDP. Hampering factors for the country's economic growth was caused by decrease in the society's productivity due to the effect of sanitation related sickness. Poor sanitation tend to increase the number of people affected to diarrhea or dengue fever [13], as the water sources are highly contaminated with microbial pathogens. These environmentally based illness covers also among others stunting, hepatitis A, leptospirosis, acute respiratory infections, skin disease, and malaria [10]. Diarrheal diseases itself causes around $11 \%$ of deaths all over the world and this burden is usually due to fecal contamination of water resources [14].

As quoted by Odagiri [15], besides increasing risk of infectious disease, poor sanitation also causes poorer cognitive development, lower educational outcomes at schools, and lower productivity in adult life. Therefore, one of SDGs goals in target 6.2 is ending open defecation and achieving universal access to sanitation, besides emphasizing on equity, dignity, gender, and sustainability.

This article aims at finding out the open defecation (OD) practice and eradication in Semarang Municipality, especially focused in Jomblang Village/Kelurahan, Candisari District. This especially based on the government's role in practicing its public administration responsibilities in the form of public service delivery.

\section{Method}

This study applies a qualitative methodology presented descriptively. Research location is Jomblang Village, Candisari District, Semarang Municipality, Central Java Province, which is near the centre of the city. The location is selected due to the fact that the local Jomblang dwellers have been practicing a healthy life, i.e. by performing waste management and creating successful Waste Bank, many times wins waste management competitions of Semarang city level. The local people's awareness and activities on waste management and environmental related activities has been excellent, as Jomblang has been many times awarded with waste management awards by the municipal government.

However, Jomblang case of open defecation is still high, 193 heads of households out of 19.805 total households [16]. In area that is close to the centre of the Semarang City, capital of Central Java. Therefore it will be very interesting to know the local dwellers' awareness on sanitation especially on open defecation behavior.

Data for this study were collected by library research, observation, and in-depth interviews. A purposive sampling technique applied to determining the research informants. The informants were selected 
because of their knowledge and role in the implementation of the Community-based Total Sanitation (STBM), which first pillar is Stop Open Defecation, (OD) in this case is in Candisari District and Kelurahan Jomblang. Technique of data analysis goes with data reduction, data presentation, and conclusion.

\section{Findings}

The sanitation development in Central Java takes place in both rural and urban areas, including Semarang Municipality, a busy trade city. According to the 2018 progress report of the Semarang Municipal CommunityBased Total Sanitation (STBM) program, 10,571 households are still practicing Open Defecation. Among them, there have been 316,543 households with lavatories or toilets. Table 1 presents the number of households in Semarang Municipality with Open Defecation practice in 2018, according to STBM Progress Report [16].

Jomblang Village, as the location of this research, is located at the center of Semarang City. It is a 22,962 $\mathrm{km}$-square area is divided into 15 Rukun Warga (United Community Unit) and 120 Rukun Tetangga (Community Unit) under the administration of Candisari District. The village is part of District Area Administration (BWK) II of Semarang Municipality and is situated nearby the downtown. It has the administrative borders as follows: Jalan Karanganyar Gunung to the North; Jalan Wahidin to the East; Jalan Tentara Pelajar to the South; and Section C Jatingaleh Highway to the West.

Data on the households with OD in Semarang and in Candisari District are as follows.

Table 1. Households with OD Practice in Semarang 2018

\begin{tabular}{|c|c|c|c|c|}
\hline \multirow{2}{*}{ No } & \multirow[b]{2}{*}{ District } & \multirow{2}{*}{$\begin{array}{c}\sum \\
\text { House- } \\
\text { holds }\end{array}$} & \multicolumn{2}{|c|}{ Baseline } \\
\hline & & & OD & Percentage \\
\hline 1 & Gunung Pati & 20,880 & 3,140 & $15.04 \%$ \\
\hline 2 & Ngaliyan & 40,529 & 1,324 & $3.27 \%$ \\
\hline 3 & $\begin{array}{l}\text { Semarang } \\
\text { Tengah }\end{array}$ & 20,918 & 0 & $0.00 \%$ \\
\hline 4 & Gayamsari & 24,139 & 276 & $1.14 \%$ \\
\hline 5 & Candisari & 19,805 & 193 & $0.97 \%$ \\
\hline 6 & $\begin{array}{l}\text { Semarang } \\
\text { Timur }\end{array}$ & 22,064 & 0 & $0.00 \%$ \\
\hline 7 & $\begin{array}{l}\text { Semarang } \\
\text { Barat }\end{array}$ & 46,426 & 244 & $0.53 \%$ \\
\hline 8 & Tembalang & 43,441 & 542 & $1.25 \%$ \\
\hline 9 & Pedurungan & 45,190 & 1,066 & $2.36 \%$ \\
\hline 10 & Mijen & 16,105 & 1,015 & $6.30 \%$ \\
\hline 11 & $\begin{array}{l}\text { Semarang } \\
\text { Utara }\end{array}$ & 30,377 & 293 & $0.96 \%$ \\
\hline 12 & $\begin{array}{l}\text { Semarang } \\
\text { Selatan }\end{array}$ & 22,123 & 1 & $0.004 \%$ \\
\hline 13 & Tugu & 8,293 & 1,354 & $16.33 \%$ \\
\hline 14 & Banyumanik & 36,498 & 811 & $2.22 \%$ \\
\hline
\end{tabular}

\begin{tabular}{|c|l|c|c|r|}
\hline \multirow{2}{*}{$\begin{array}{c}\text { No } \\
\cdot\end{array}$} & District & \multirow{2}{|c|}{$\begin{array}{c}\Sigma \\
\text { House- } \\
\text { holds }\end{array}$} & OD & Percentage \\
\hline 15 & Gajahmungkur & 14,941 & 0 & $0.00 \%$ \\
\hline 16 & Genuk & 27,623 & 312 & $1.13 \%$ \\
\hline \multicolumn{4}{|c|}{ Tource: STBM Progress Report [16] } \\
\hline
\end{tabular}

Data in Table 1 proves that 10,571 households across the municipality still practice open defecation with Candisari District being among the high rate $(0.97 \%)$, in which Jombang Village is one of its prominent village because has already performed a good waste management and established a prominent waste bank, among others reflects the high awareness of the local people in managing their environment well. Meanwhile, Table 2 provides data on the households with open defecation practice in Candisari District in 2018.

Semarang Municipal Office of Health Affairs in collaboration with entrepreneurs and health professional organizations have been making a joint effort towards the Open Defecation Free (ODF) target by the end of 2018 [7], a year faster of the Indonesian government's target in 2019, since Semarang was among areas designated for ODF in the first phase (2017). Almost all of the villages in Candisari have openly declared their participation in eradicating open defecation by 2018, following declaration in Tambak Aji Village [18]. However, the implementation of this goal is not easy to realize.

Table 2. Households with OD Practice in Candisari 2018

\begin{tabular}{|c|c|c|c|c|}
\hline \multirow[b]{2}{*}{ No. } & \multirow[b]{2}{*}{ Village } & \multirow{2}{*}{$\begin{array}{c}\text { Data } \\
\text { Identity } \\
(\Sigma \text { data }) \\
\sum \\
\text { households }\end{array}$} & \multicolumn{2}{|c|}{ Baseline } \\
\hline & & & OD & Percentage \\
\hline 1 & Jatingaleh & & 53 & $1.82 \%$ \\
\hline 2 & $\begin{array}{l}\text { Karanganyar } \\
\text { Gunung }\end{array}$ & 2,496 & 50 & $2.00 \%$ \\
\hline 3 & Jomblang & 5,756 & 50 & $0.87 \%$ \\
\hline 4 & Candi & 2,827 & 19 & $0.67 \%$ \\
\hline 5 & Kaliwiru & 859 & 0 & $0.00 \%$ \\
\hline 6 & Wonotingal & 2,010 & 12 & $0.59 \%$ \\
\hline 7 & Tegalsari & 2,950 & 9 & $0.31 \%$ \\
\hline \multicolumn{2}{|c|}{ Total } & 19,805 & 193 & \\
\hline
\end{tabular}

Source: STBM Progress Report [16]

First, the fact that Semarang is one of cities with a high open defecation rate, is a shocking fact for many Semarang City dwellers, especially those who are not (very) familiar with health issues. During the initiation of this research, many Semarang dwellers interviewed on their knowledge about open defecation (OD) phenomenon in Semarang were really surprised that Semarang is included in the OD eradication program in Central Java.

Students of two classes at Master Program of Public Administration at Universitas Diponegoro as 
informants were asked on what they knew about ODF case in Indonesia. Some $85 \%$ out of 28 students said that $\mathrm{OD}$ is only found in rural areas, something that is not true in a country so diverse like Indonesia. When they were asked about OD case in Semarang, they did not have any knowledge on that issue. All of them were then shocked when were informed that OD is actually a real phenomenon in Semarang City. This fact was also happened in some people from Candisari District, who were asked about ODF case in their area. Surprisingly, these Candisari inhabitants did not have any knowledge at all that Candisari is one among areas with OD case in Semarang.

Sanitation development by providing toilets and lavatories is indeed still a major problem in Indonesia, not only from the people's side but also from the government's part. According to data from Ministry of Health [12], the United Nations in 2010 announced that health is among human rights, which therefore must be fulfilled by the government.

However, there are stakeholders and decisionmakers, either from executive or legislative branch, who have not had a clear understanding about the importance of sanitation. Therefore, they tend to consider it as secondary matter to other programs, in particular those with immediate impacts such as infrastructure programs. According to recapitulation of the Local Income and Spending Budget (APBD) for regency/municipal levels in Central Java, the sanitation budget is still considered inadequate, only $1-2 \%$ of the total budget [17].

Meanwhile, according to observation, the open defecation practice in Jomblang correlates to improper behavior of the urban dwellers who live nearby the river or watershed, as the research finds in Jomblang. The Jomblang local dwellers use Bajak River which flows in their area to defecate, mostly by canaling their waste from the toilet straight to the river. The reason for such bad habit is limited access to lavatory or toilet with proper septic tank due to high population density and crowed settlement leaving almost no space for septic tank facilities. There is a house which was formerly equipped with septic tank facilities, but then found without septic tank during the research. This is due to erosion from the river which eventually erode the lavatory area, since this house is located just at the bank of the river.

Beside the above reasons, many of the local dwellers who are still practicing open defecation are people with low income and, therefore, find that making septic tank infrastructure is too expensive. Economic level indeed also contributes to the open defecation practice, since the people cannot afford to provide themselves with any lavatory or toilet amidst their intention to materialize the ODF programme.

However, it is quite strange that there are households which actually live in quite expensive house, but has no latrines. The owners must have money to build septic tank facilities rather than just canalling the toilet waste straight into Bajak River, just as being practiced by households in Kemiri village, Bojonegoro, which location is circled with Bengawan Solo River [8]. This specific Jomblang fact is not in line with Abubakar's statement that OD is the strongest expression of extreme poverty [19]. Informant who is owner of the house stated that they have been practicing this for years. If the government wants to eradicate open defecation in this area, the government must provide the fund for constructing septic tank. It is strange wish since actually any household must be responsible for its own toilet waste.

Another problem relates to open defecation is the reluctance of the city dwellers to use toilet or lavatory to defecate since they have got used to practicing the OD. This is corresponds with Odagiri's research in rural Indonesia that $\mathrm{OD}$ is very much related to the respondents' perceptions around latrine ownership, besides the people wealth level and all-year round water access for household needs [15].

In Jomblang only very few practicing this habit. Most local dwellers households with OD just simply do not have any latrines which is then included into practicing OD. Jomblang has a prominent position in Semarang City in its waste management, thanks to its some local informal natural leaders. They show strong commitment and consistency in encouraging their neighbors. This paternalistic norms which still exist in Indonesian community, including in Jomblang, should be directed more to make OD program successful. In Jomblang, those having latrines, must be encouraged to use them. This problems also appears in India, in which an estimated 360 million people do not have access to latrines. The OD elimination program strives to make two major changes namely increase the number of households that have latrines, and increase the number of household members using latrines [20].

The government of Semarang plans to build communal latrine, as part of government's public service delivery to meet this very important service needed by the local dwellers. However, the interviewed informal leaders argue that this communal latrine will give be beneficial and be well maintained by the local people. Instead, they suggests for simple, low cost technology applied in the people's house, and moreover added with sound financial scheme. This is in line with Dreibelbis argument on the importance of promotion and provision of low-cost technologies that would enable improved water, sanitation, and hygiene practices for reducing enteric illnesses in low-income countries [21]. Participation of the local people is the most important key, as the government itself will not be able to provide all of the public service need in health sector, although in the public administration sphere it is the government's responsibility.

\section{Closing}

Open Defecation (OD) problem in Jomblang Village, Candisari District, Semarang City must be eliminated by the government. Good health management must be implemented as parts of government's 
obligation in delivering health public service, but not yet well committed. This is an urgent task since OD could potentially lead into various sickness. The Jomblang dwellers deserves to get a better community health service. However, successful Open Defecation Free (ODF) programme needs active participation of the local dwellers, and especially with natural leaders' strong commitment to reinforce normative expectation, as paternalistic norms still exist in Indonesian community. This is in addition to the responsibility of the government as the service provider. In this case is in health service, which is one of the most important service it must provide besides education service. Especially after the issuance of Law Number 32 of 2004 on Local Autonomy, upon which the local government is responsible more on the welfare of its people.

\section{References}

1. WHO/UNICEF Joint Monitoring Programme. Progress on Sanitation and Drinking Water - 2017 Update and SDG Baseline. WHO; Geneva, Switzerland. (2017).

2. J.O. Okullo, W.N. Moturi, G.Ogendi, Research Article https://journals.sagepub.com/doi/full/10.117 7/1178630217735539

3. https://properti.kompas.com/read/2013/10/31/1209 048/Indonesia.Negara.dengan.Sanitasi.Terburuk.Ke dua.di.Dunia.m, accessed on July 17, 2018.

4. http://stbmindonesia.org/monev/index.php/pilar_1/ provinsi/33, accessed on July 17, 2018.

5. http://dinkes.sumutprov.go.id/artikel-206-buangair--besar-sembarangan-babs.html, accessed on July 17, (2018)

6. Minister of Health Number 852/ MENKES/ SK/ IX/ 2008 on Community Based Total Sanitation (CBTS) program

7. The Health Office of Central Java Province, The Strategy of Community-Based Total Sanitation (CBTS) in Central Java Province, Indonesia, (2017)
8. S. Sholikhah. J Surya, 02, 84 - 90. (2014).

9. UNICEF/WHO. Progress on Sanitation and Drinking Water - 2015 Update and MDG Assessment, World Health Organization, Geneva. (2015)

10. Dinas Kesehatan Jawa Tengah (The Health Office of Central Java Province), material from the Coordination Meeting of Sanitation Delivery for Central Java Inhabitants (2017)

11. http://radarsemarang.com/2018/05/02/582-kkbuang-air-besar-sembarangan/2 Mei (2018)

12. http://www.depkes.go.id/pdf.php?id=16060100003, accessed on July 10,(2018)

13. A.Purnomo, N. Khairina, Planning of decentralized wastewater treatment in RW 9, Genteng Sub district, Surabaya City, J Soc and Behav Sci, 227 (2016) 791-798.

14. R. Abaka-Yankson, S.Shaw, Annual Global Health, 83, 1, (2017).

15. M.Odagiri, Z.Muhammad. A.A.Cronin, M.E. Gnilo, A.K. Mardikanto,K.Umam, Y.T. Asamou, Int J. Environ Res Public Health 2017 12, 1572, (2017)

16. http://stbm.kemkes.go.id/monev/index.php/pilar_1/ kecamatan/33/3374/3374060, accessed on July 17 , (2018)

17. http://www.airminum.or.id/sanitasil/category/jawa $\% 20$ tengah/3, accessed on July 17, (2018).

18. https://tribratanews.jateng.polri.go.id/2018/02/15/b habinkamtibmas-polsek-ngaliyan-laksanakandeklarasi-odf/ accessed 10 July (2018).

19. I.R. Abubakar, Sci and Total Envir, 637-638 (2018)

20. K.O'Reilly, R. Dhanju, A. Goel, World Development, 93, 193 - 205 (2017)

21. R.Dreibelbis, PJ Winch, E. Leontsini, KRS Hulland, PK Ram, L.Unicomb, SP Luby, $B M C$ Public Health 13:1015 (2013).

22. Law Number 32 of 2004 on Local Autonomy 